\begin{tabular}{cc}
\hline International Journal of Physical Research, $8(2)(2020) 55-59$ \\
International Journal of Physical Research \\
Website $:$ www.sciencepubco.com/index.php/IJPR \\
Research paper
\end{tabular}

\title{
Assessment of heavy metals and radioactivity concentrations in Iraqi truffles
}

\author{
Sahar A. Amin ${ }^{1}$, Afaf A. Ayoub ${ }^{1}$, Athmar A. AlMashhady ${ }^{1}$, Ali N. Ali ${ }^{1}$, Ehab M. Abdul Hadi ${ }^{1}$ \\ ${ }^{1}$ Environment Research Center, University of Technology- Iraq \\ *Corresponding author E-mail: sahar.a.amin@uotechnology.edu.iq
}

\begin{abstract}
Concentrations of heavy metals in several species of desert truffles, collected from different Iraqi provinces, were determined. Samples were collected from Al-Anbar Salah ad-Den and AlMuthana provinces. The levels of $\mathrm{Cd}, \mathrm{Cr}, \mathrm{Pb}, \mathrm{Mn}, \mathrm{Ni}$, and $\mathrm{Zn}$ were analyzed. As well as the level of radon in the truffle samples were also measured using the solid-state nuclear track detector (CR-39). The results reveal that the concentrations of the investigated elements in the Iraqi truffles were below the recommended levels and the ascending order of the measured toxic elements was $\mathrm{Ni}<\mathrm{Mn}<\mathrm{Zn}$. The concentrations of the other elements $(\mathrm{Cd}, \mathrm{Cr}$ and $\mathrm{Pb})$ were below the detection limit of the measuring method. Radon activity levels in the study truffle samples were between (156.23 to 513.83) Bq.m-3 with mean value of (323.23) Bq.m-3. the results reveal that most measured radon activity were below the world recommended value given by ICRP except Ramadi sample. All the computed values of health risk index (HR) of all elements were within safe limits $(\mathrm{HR}<1)$, therefore, the consumption of the investigated truffles does not pose any health risks from the investigated heavy elements and from radiological point of view.
\end{abstract}

Keywords: Atomic Absorption Spectroscopy; CR-39; Desert Truffles; Health Risk Assessment; Heavy Metal; Radon.

\section{Introduction}

Desert truffles are a very common and appreciated food in many Middle East countries. The desert truffles have a number of special features. They have a high economic value and are the world's most expensive truffles [1]. Desert truffles have a distinguishable chemical characteristic compared with other common everyday consumed truffles [1-3]. They have generally no stem, no gills, and they grow underground. Mature truffles have a tendency to be intense and hard rather than have mushy and delicate characteristics [2]. They have good taste and there are many researches about their health advantages [4]. Desert truffles can be concerned as antioxidants fruit because they contain many polyphenolic compositions [5], as well as, the studies show that truffles have antimicrobial [6], [7], antioxidant [8] and hepato-protective activity [9].

Several studies on chemical composition of desert truffles show that they contain high protein and amino acids and they are rich in fiber, fatty acids (linoleic, palmitic, oleic), minerals (such as $\mathrm{K}, \mathrm{P}, \mathrm{Fe}, \mathrm{Ca}$ and $\mathrm{S}$ ) as well as carbohydrates which they may enhance people health [4], [10-14]. There are various types of truffles around the worlds but only two kinds of truffles in Iraq, the black truffles which belong to the genus Terfezia and the other one is the white truffles which belong to the genus Tirmania which is usually grow in Al Muthana province [15]. Both types are known by the arabic name kamah. In Iraq and in many Gulf countries, the truffles usually grow in the deserts during winter (the rainy season) [16]. As Terfezia and Tirmania are habitually spread to the arid and semi-arid parts of the Mediterranean, therefore they are also called desert truffles [1], [2].

Two main goals for this research: examining whether the truffle fruiting bodies can be considered as bio-indicators of ecological pollution and investigating whether they accumulate high levels of some trace elements.

\section{Materials and methods}

\subsection{Plant sampling}

Samples of black truffles were collected from different cities in Al-Anbar province (Anah, Haditha and Ramadi) as well as one sample was collected from Salah ad-Den province. One white truffle sample was collected from Al Muthana province. The samples were stored in labeled polythene sampling bags and brought to the Environmental Research Center, University of Technology, Baghdad, Iraq. The truffles samples were washed with tap water to remove any kind of deposition like soil particles. Then truffles were oven dried and ground into powdered form, sieved with $0.3 \mathrm{~mm}$ mesh size and they stored in polyethylene bags to prepare the samples for digesting. $10 \mathrm{~g}$ of each sample was put in plastic containers in order to measure radon concentration.

\subsection{Heavy metals analysis}


a) Digestion of samples

A weight of $1 \mathrm{~g}$ of each desert truffle samples was digested by $16 \mathrm{ml}$ acid mixture (f) at 2:6 ratio and heated on a hot plate at Temperature $120^{\circ} \mathrm{C}$ until the transparent solution appeared. When the solution becomes cold, $10 \mathrm{ml}$ of distilled water was added. Then the liquid samples were filtered through Whatman No. 42 filter papers and made up to $50 \mathrm{ml}$ volume using deionized distilled water. The samples were kept for 24 hours to allow the solution to settle and stored for further analysis.

Concentrations of heavy metal samples were analyzed using Atomic Absorption Spectrophotometer (AA-6300 SHIMADZU - Japan) according to standard method 3030E at the Environmental Research Center laboratory, University of Technology, Baghdad.

b) Quality control analysis

Chemicals were supplied from fine-CHEM limited, MUMBAI, India and used for the sample preparation. Double deionized water was used for solution preparation and glassware was washed with $10 \% \mathrm{HNO}_{3}$. Standards were prepared for each metal from their stock solution to calibrate the instrument.

c) Data analysis

i) Average daily intake of metals (ADI)

In this study, the risks to human health posed by chronic exposure to heavy metals were assessed. The average daily intake of metal was evaluated for the study of potential health risk assessment, in accordance with Eq. 1[17]

$\mathrm{ADI}=\frac{\mathrm{C}_{\mathrm{m}} \times \mathrm{C}_{\mathrm{f}} \times \mathrm{D}_{\mathrm{FI}}}{\mathrm{B}_{\mathrm{AVW}}}$

Where $C_{m}, C_{f}$, and $D_{F I}$ represent the heavy metal concentrations in analyzed foodstuffs $(\mathrm{mg} / \mathrm{kg})$, conversion factor $(0.085)$ and daily intake of truffle (30 g per person per day), respectively (Mahmood and Malik, 2014). Also, $\mathrm{B}_{\mathrm{avw}}$ indicates average body weight equaling $60 \mathrm{~kg}$ for adults [18].

ii) Health risk index (HR)

To assess the human health risk of heavy metals, it is necessary to calculate the level of human exposure to that metal by tracing the route of exposure of pollutant to human body. A higher concentration of heavy metals which enters the human body leading to health risks [19]. In the present research work, metal concentration was used to calculate the health risk index (HR). Value of HR depends upon the average daily intake of metals (ADI) and oral reference dose $\left(\mathrm{D}_{\text {ref }}\right)$. $\mathrm{D}_{\text {ref }}$ is an estimated per day exposure of metal to the human body that has no hazardous effect during life time [20]. The health risk index for the measured heavy metals by consumption of desert truffles was calculated by following equation [17]

$$
\mathrm{HR}=\frac{\mathrm{ADI}}{\mathrm{D}_{\mathrm{ref}}}
$$

Where, ADI indicates daily intake of metal $(\mathrm{mg})$ and $\mathrm{D}_{\text {ref }}$ refers to reference dose of metal $(\mathrm{mg} / \mathrm{kg} /$ day). The oral reference doses were 0.14 for $\mathrm{Mn}, 0.02$ for $\mathrm{Ni}$ and 0.30 for $\mathrm{Zn}$ ( $\mathrm{mg} / \mathrm{kg}$ body weight/day). Also, an $\mathrm{HR}<1$ means the truffle consumption is assumed to be safe [2123].

Total HR (THR) of elements for the Truffles was evaluated in accordance with Eq. 3 [17]

$\mathrm{THR}=\mathrm{HR}_{\text {toxicant1 }}+\mathrm{HR}_{\text {toxicant2 }}+\mathrm{HR}_{\text {toxicant }}+\cdots+\mathrm{HR}_{\text {toxicantn }}$

\subsection{Radon measurement}

The solid-state nuclear track detection technique (SSNTD) (sealed can technique) was used during the present study. The CR-39 nuclear track detector sheet was cut into small pieces each of $\left(1.5 \times 1.5 \mathrm{~cm}^{2}\right)$ area. Equal amount of the dried samples $(30$ gm) placed in the plastic container of radius $(4 \mathrm{~cm})$ and height $(10 \mathrm{~cm})$ to ensure radon detection only. The $C R-39$ pieces were placed in the bottom of each container cover, with samples at the bottom of the container and then left for exposure of 60 days. At the end of exposure time the collected CR-39 detectors were chemically etched using a $6.25 \mathrm{~N}$ solution of $\mathrm{NaOH}$, at temperature of $70^{\circ} \mathrm{C}$, for a period of $5 \mathrm{hrs}$ in the etching bath. An optical microscope with magnification of $400 \mathrm{X}$ was used to count the number of tracks per FOV in each detector and subsequently the average radon (Rn-222) concentration in $\mathrm{Bq} / \mathrm{m}^{3}$ have been calculated. The activity concentrations of radon in $\left(\mathrm{Bq} / \mathrm{m}^{3}\right)$ for truffle samples have been obtained using the expression [24]:

$$
\mathrm{C}(\mathrm{Rn})=\frac{\rho}{\mathrm{K} \cdot \mathrm{T}}
$$

Where, $\rho$ is the radon track density (Track $\mathrm{cm}^{-2}$ ) which it is calculated by number of tracks per area of field of view $\left(\right.$ Tracks/ $\left.\mathrm{cm}^{2}\right)$, $\mathrm{T}$ is the exposure time and $\mathrm{K}$ is the calibration factor. The Concentration of uranium (ppm) was calculated using the formula

$$
\mathrm{C}_{\mathrm{u}}(\mathrm{ppm})=\frac{\mathrm{W}_{\mathrm{U}}}{\mathrm{W}_{\mathrm{s}}}
$$

Where, $\mathrm{W}_{\mathrm{u}}$ and $\mathrm{W}_{\mathrm{s}}$ are the weight of uranium in the sample and the weight of the sample.

\section{Results}

\subsection{Heavy metals}

The concentrations of six metals $(\mathrm{Mn}, \mathrm{Ni}, \mathrm{Zn}, \mathrm{Cd}, \mathrm{Cr}$ and $\mathrm{Pb}$ ) in Iraqi truffle samples were measured and shown in Table 1. Figures (1-3) illustrate the concentrations of $\mathrm{Mn}, \mathrm{Ni}$ and $\mathrm{Zn}$, respectively. The lowest $\mathrm{Zn}$ observed concentration was $(0.5481) \mathrm{mg} / \mathrm{kg}$ in sample T6 collected from Salah ad-din province, while the highest observed concentration was (1.1134) $\mathrm{mg} / \mathrm{kg}$ in sample T2 collected from Anah city. The Mn concentration ranged from $(0.1725) \mathrm{mg} / \mathrm{kg}$ to $(1.2274) \mathrm{mg} / \mathrm{kg}$. The lowest Mn level detected was in samples T2 (Anah city) and T4 (Al Muthanna province), whereas the highest Mn level detected was in sample T5 (Haditha city). The concentration of Ni metal was ranged from $(0.0601) \mathrm{mg} / \mathrm{kg}$ to $(0.1474) \mathrm{mg} / \mathrm{kg}$ in T4 (Al Muthanna province) and T5 (Haditha) samples, respectively. 
However, the concentration of the toxic metals $(\mathrm{Cd}, \mathrm{Cr}$ and $\mathrm{Pb})$ were tried to be analyzed but they were below detection limit which are $(0.2,0.1$ and $1 \mathrm{mg} / \mathrm{kg})$, respectively. Among the six determined metals $\mathrm{Zn}$ was the highest in all truffle samples (Table 1).

As it was shown in Table 1, the order of harmful element levels was $\mathrm{Ni}<\mathrm{Mn}<\mathrm{Zn}$ in both types of truffles.

Table 1: Mean Values of Heavy Metal Concentrations

\begin{tabular}{|c|c|c|c|c|c|c|c|}
\hline \multicolumn{8}{|c|}{ Heavy Metal concentration (mg/kg) } \\
\hline City & Code & $\mathrm{Mn}$ & $\mathrm{Ni}$ & $\mathrm{Zn}$ & $\mathrm{Cd}$ & $\mathrm{Cr}$ & $\mathrm{Pb}$ \\
\hline Ramadi & $\mathrm{T} 1$ & 0.4415 & 0.1147 & 0.6595 & ND & ND & ND \\
\hline Anah & $\mathrm{T} 2$ & 0.1725 & 0.0855 & 0.5481 & ND & ND & ND \\
\hline Ramadi & $\mathrm{T} 3$ & 0.2129 & 0.0928 & 0.6194 & ND & ND & ND \\
\hline Al Muthanna & $\mathrm{T} 4$ & 0.1725 & 0.0601 & 0.6207 & ND & ND & ND \\
\hline Haditha & $\mathrm{T} 5$ & 1.2274 & 0.1474 & 1.0281 & ND & ND & ND \\
\hline Salah ad-Din & T6 & 0.7317 & 0.1037 & 1.1134 & ND & ND & ND \\
\hline
\end{tabular}

The Joint FAO/WHO Expert Committee on Food Additives [25] recommends that provisional tolerable weekly intakes (PTWI) of Ni, and $\mathrm{Zn}$ are 35 and $420 \mu \mathrm{g} / \mathrm{kg} /$ week, respectively, while, there is no PTWI data for Mn. Therefore, the weekly tolerable intakes of Ni and Zn for a person weighing $60 \mathrm{~kg}$ would be 2.1 and $25.2 \mathrm{mg}$, respectively [18].

Considering the average body weight $(60 \mathrm{~kg})$ of an adult, fresh Truffle consumption (30 g daily) and median concentration in (mg/kg bw/wk) of $\mathrm{Mn}, \mathrm{Ni}$, and $\mathrm{Zn}$ in truffle found in this study $0.01796,0.00367$ and 0.02786 then the estimated mean $\mathrm{HR}$ for $\mathrm{Mn}, \mathrm{Ni}, \mathrm{Zn}$ and THR are $0.1283,0.18342,0.09288$ and 0.40460 , respectively (Table 2). All the values of HRs and THR based on median concentration were less than one (closer to zero), suggesting that consumption of the investigated truffles do not pose any health risks from investigated elements for Iraqi consumers.

Table 2: Daily Intake of Metals ( $\mathrm{Mg} / \mathrm{Kg} \mathrm{Bw} / \mathrm{Wk})$, Health Risk Index and Total Health Risk Index in Desert Truffles

\begin{tabular}{|c|c|c|c|c|c|c|c|}
\hline \multirow{2}{*}{ Sample Code } & \multirow{2}{*}{$\begin{array}{l}\text { ADI } \\
\mathrm{Mn}\end{array}$} & \multirow[b]{2}{*}{$\mathrm{Ni}$} & \multirow[b]{2}{*}{$\mathrm{Zn}$} & \multicolumn{2}{|l|}{ HR } & \multirow[b]{2}{*}{$\mathrm{Zn}$} & \multirow{2}{*}{ THR } \\
\hline & & & & $\mathrm{Mn}$ & $\mathrm{Ni}$ & & \\
\hline $\mathrm{T} 1$ & 0.11258 & 0.02925 & 0.16817 & 0.11488 & 0.20892 & 0.08008 & 0.40388 \\
\hline $\mathrm{T} 2$ & 0.04399 & 0.02180 & 0.13977 & 0.04489 & 0.15573 & 0.06656 & 0.26717 \\
\hline T3 & 0.05429 & 0.02366 & 0.15795 & 0.05540 & 0.16903 & 0.07521 & 0.29964 \\
\hline $\mathrm{T} 4$ & 0.04399 & 0.01533 & 0.15828 & 0.04489 & 0.10947 & 0.07537 & 0.22972 \\
\hline T5 & 0.31299 & 0.03759 & 0.26217 & 0.31937 & 0.26848 & 0.12484 & 0.71269 \\
\hline T6 & 0.18658 & 0.02644 & 0.28392 & 0.19039 & 0.18888 & 0.13520 & 0.51447 \\
\hline Mean & 0.12574 & 0.02568 & 0.19504 & 0.12830 & 0.18342 & 0.09288 & 0.40460 \\
\hline PTWI & No data & 2.1 & 25.2 & $\mathrm{HR}<1$ & & & \\
\hline
\end{tabular}

PTWI - Provisional Tolerably Weekly Intake (mg per kg of body weight) established by JECFA.

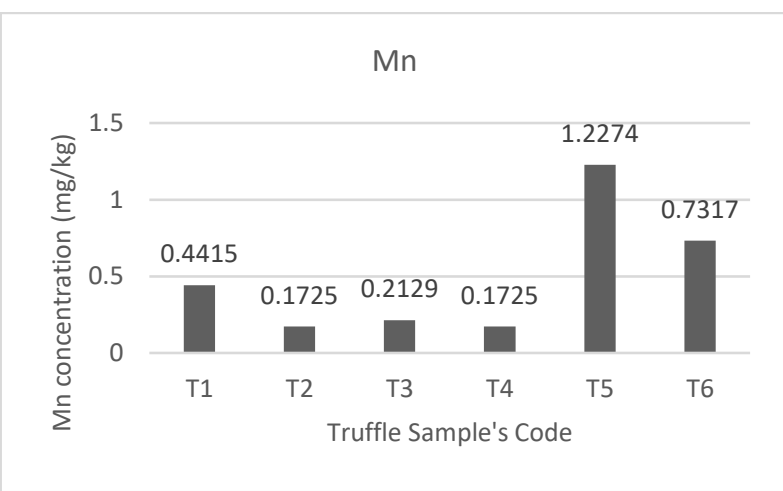

Fig. 1: Mn Concentration in Truffle Samples.

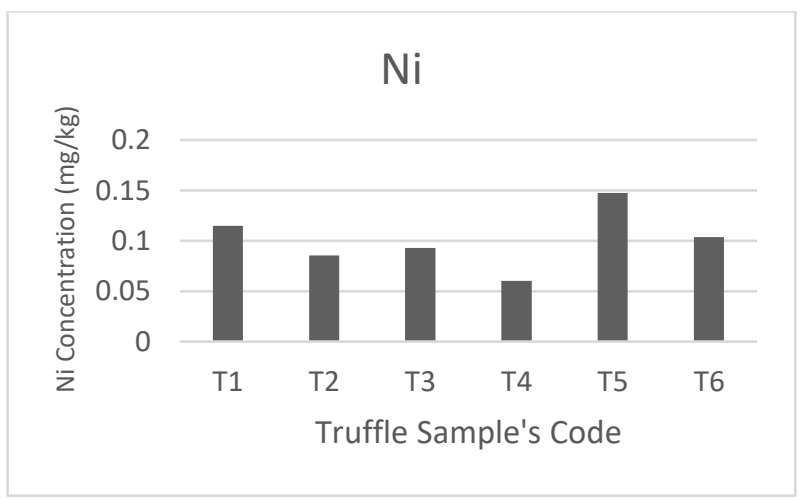

Fig. 2: Ni Concentration in Truffle Samples. 


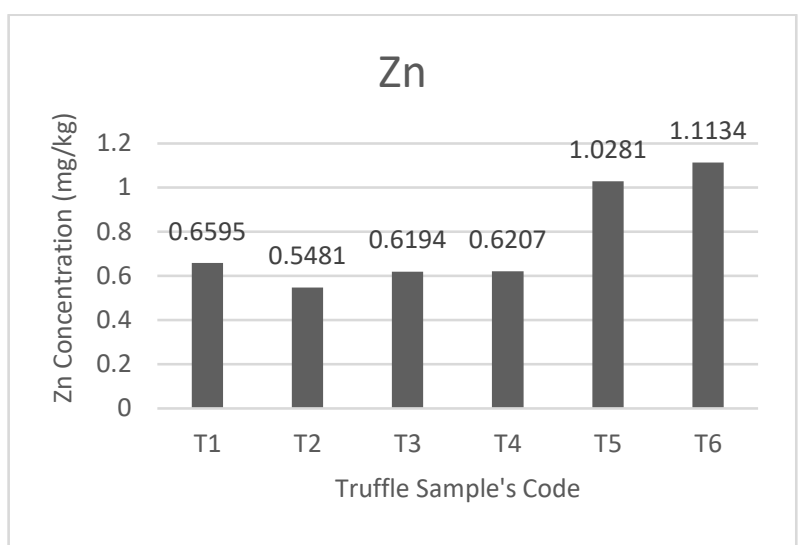

Fig. 3: Zn Concentration in Truffle Samples.

\subsection{Radon concentration}

The activity concentration of radon in the measured truffle samples is given in Table 3 . The mean value of radon concentration was 323.23 Bq. $\mathrm{m}^{3}$ with the highest value of $513.83 \mathrm{~Bq} \cdot \mathrm{m}^{3}$ and the lowest value of $156.23 \mathrm{~Bq} \cdot \mathrm{m}^{-3}$ in Ramadi Truffle sample and Haditha Truffle sample respectively. Highest value of $\mathrm{C}_{U}$ was $0.092 \mathrm{ppm}$ and the lowest value was $0.028 \mathrm{ppm}$ with an average value of $0.058 \mathrm{ppm}$. The differences in the radon activity concentrations due to the differences in the level of radioactive materials concentrations and the differences in the geological formation of the soil where the truffles grew. The results show that all values of radon concentration are lower than the recommended value of $400 \mathrm{~Bq} \cdot \mathrm{m}^{-3}$ given by ICRP [26].

Table 3: Radon Activity Concentration $\left(\mathrm{Bq}_{\mathrm{M}} \mathrm{M}^{-3}\right)$ and Uranium Concentration (Ppm) for the Study Truffle Samples

\begin{tabular}{|c|c|c|c|}
\hline City & Sample & $\mathrm{C}_{\mathrm{Rn}}$ & $\mathrm{C}_{\mathrm{U}}$ \\
\hline Ramadi & $\mathrm{T} 1$ & 513.83 & 0.092 \\
\hline Anah & $\mathrm{T} 2$ & 227.41 & 0.041 \\
\hline Al Muthanna & $\mathrm{T} 4$ & 277.75 & 0.050 \\
\hline Haditha & T5 & 156.23 & 0.028 \\
\hline Salah ad-Din & T6 & 328.09 & 0.059 \\
\hline Mean & & 323.23 & 0.058 \\
\hline Min & & 156.23 & 0.028 \\
\hline Max & & 513.83 & 0.092 \\
\hline
\end{tabular}

\section{Conclusions}

Heavy metal concentrations in desert truffles, Terfezia and Tirmania have been determined on a dry weight basis using atomic absorption spectroscopy. It was observed that the heavy metal concentration ranged from $0.1725-1.2274$ for $\mathrm{Mn}, 0.0601-0.1474 \mathrm{mg} / \mathrm{kg}$ for Ni, 0.5481 $1.1134 \mathrm{mg} / \mathrm{kg}$ for $\mathrm{Zn}$, whereas the concentrations of $\mathrm{Cd}, \mathrm{Cr}$ and $\mathrm{Pb}$ were below the detection limit of the used method.

The order of the levels of heavy metals in the truffle samples was found to be; $\mathrm{Ni}<\mathrm{Mn}<\mathrm{Zn}$. The study also shows that the measured toxic metals content in all the samples was under permissible level. This may imply that consumption of these truffles has no deleterious effects in health if consumed in proper amounts. However, HR was also calculated and its value was less than 1 in all investigated samples. Future work should focus on measuring the levels of other metals, in order to supply more information for risk assessment.

Radon activity concentration was also been measured using CR-39 solid state nuclear track detector. The values of the radon activity samples were below the world recommended value given by ICRP except for the sample T1 which was higher than the world recommended value. However, the results indicate that the radon activity level does not exceed the safe limit for radon activity concentration and there are no health hazards concerning truffle consuming.

\section{References}

[1] E. Luard, Truffles, Frances Lincoln Limited, 2006.

[2] I. R. Hall, G. T. Brown, A. Zambonelli, Taming the truffle, the history, lore, and science of the ultimate mushroom, Timber press, 2007. www.timberpress.com.

[3] S. Jamali, Z. Banihashemi, Nested-Pcr for detecting terfezia claveryi in roots of helianthemum species in field and greenhouse conditions, Journal of Agriculture Science and Technology, 15 (2013) 377-388. http://jast.modares.ac.ir/article-23-12166-en.html.

[4] S. Wang, M. F. Marcone, The biochemistry and biological properties of the world's most expensive underground edible mushroom: truffles, Food Research International, 44 (2011) 2567-2581. https://doi.org/10.1016/j.foodres.2011.06.008.

[5] L. Barros, M. Ferreira, B. Queiros, I. C. F. R. Ferreira, P. Baptista 2007. Total phenols, ascorbic acid, $\beta$-carotene and lycopene in Portuguese wild edible mushrooms and their antioxidant activities, Food chemistry, 103(2) (2007) 413-419. https://doi.org/10.1016/j.foodchem.2006.07.038.

[6] H. Gouzi, L. Belyagoubi, K. N. Abdelali, A. Khelifi, In vitro antibacterial activities of aqueous extracts from algerian desert truffles (terfezia and tirmania, ascomycetes) against pseudomonas aeruginosa and staphylococcus aureus, International Journal of Medicinal Mushrooms, 13(6) (2011) 553-558. https://doi.org/10.1615/IntJMedMushr.v13.i6.70.

[7] S. Janakat, S. Al-Fakhiri, A. K. Sallal, 2004. A promising peptide antibiotic from Terfezia Claveryi aqueous extract against staphylococcus aureus in vitro, Phytotherapy Research, 18(10) (2004) 810-813. https://doi.org/10.1002/ptr.1563.

[8] A. Al-Laith, Antioxidant components and antioxidant/antiradical activities of desert truffle (Tirmania Nivea) from various middle eastern origins, Journal of Food Composition and Analysis, 23(1) (2010) 15-22. https://doi.org/10.1016/j.jfca.2009.07.005.

[9] S. Janakat, M. Nassar, Hepatoprotective activity of desert truffle (terfezia claveryi) in comparison with the effect of nigella sativa in the rat, Pakistan J. Nut, 9 (2010) 52-56. https://doi.org/10.3923/pjn.2010.52.56.

[10] H. Bokhary, S. Parvez, Chemical composition of desert truffles Terfezia Claveryi, Journal of Food Composition Analysis, 6 (1993) $285-293$. https://doi.org/10.1006/jfca.1993.1031. 
[11] V. Kagan-Zur, N. Roth-Bejerano, Y. Sitrit, A. Morte, Desert truffles: phylogeny, physiology, distribution and domestication, Springer Science \& Business Media, 2013. https://doi.org/10.1007/978-3-642-40096-4.

[12] M. A. Murcia, M. Martínez-Tomé, A.Vera, A. Morte, A. Gutierrez, M. Honrubia, A.M. Jiménez, Effect of industrial processing on desert truffles Terfezia, Journal of the Science and Food Agriculture 83 (2003). https://doi.org/10.1002/jsfa.1397.

[13] A. A. Ahmed, M. A. Mohamed, M. Hami, Libyan truffles (Terfezia Boudieri Chatin): chemical composition and toxicity, Journal of Food Science, 46 (1981) 927-929. https://doi.org/10.1111/j.1365-2621.1981.tb15383.x.

[14] W. Sawaya, A. Al-Shalhat, A. Al-Sogair, M. Al-Mohammad, 1985. Chemical composition and nutritive value of truffles of Saudi Arabia, Journal of Food Science, 50(2) (1985) 450-453. https://doi.org/10.1111/j.1365-2621.1985.tb13425.x.

[15] S. Jamali, Z. Banihashemi, 2012. Hosts and distribution of desert truffles in Iran, based on morphological and molecular criteria, Journal of Agriculture Science and Technology, 14(6) (2012) 1379-1396.

[16] I. M. Al-Ruqaie, Effect of different treatment processes and preservation methods on the quality of truffles: I. Conventional methods (drying/freezing), Pakistan Journal of Biological Sciences, 5 (10) (2002) 1088-1093. https://doi.org/10.3923/pjbs.2002.1088.1093.

[17] J. Guo, T. Yue, X. Li, Y. Yuan, Heavy metal levels in kiwifruit orchard soils and trees and its potential health risk assessment in Shaanxi, China, Environmental Science and Pollution Research, 23(14) (2016) 14560-6. https://doi.org/10.1007/s11356-016-6620-6.

[18] United State Environmental Protection Agency (USEPA), Integrated Risk Information System; Washington, DC, USA, 2002.

[19] S. Khan, Q. Cao, Y. M. Zheng, Y. Z. Huang, Y. G. Zhu, Health risks of heavy metals in contaminated soils and food crops irrigated with wastewater in Beijing. China Environmental Pollution, 152(3) (2008) 686-692. https://doi.org/10.1016/j.envpol.2007.06.056.

[20] United States, Environmental Protection Agency, Integrated Risk Information System USEPA IRIS, (2006). http://www.epa.gov/iris/substS.

[21] Z. J.Xue, S.Q. Liu, Y. L. Liu, Y.L. Yan, Health risk assessment of heavy metals for edible parts of vegetables grown in sewage-irrigated soils in suburbs of Baoding City, China, Environmental Monitoring and Assessment 184(6) (2012)3503-13. https://doi.org/10.1007/s10661-011-2204-6.

[22] Q. Liang, Z. J. Xue, F. Wang, Z. M. Sun, Z. X.Yang, S. Q. Liu, Contamination and health risks from heavy metals in cultivated soil in Zhangjiakou City of Hebei Province, China, Environmental Monitoring and Assessment, 187(12) (2015) 754. 34. https://doi.org/10.1007/s10661-015-4955-y.

[23] X. Zeng, Z. Wang, J. Wang, J. Guo, X. Chen, J. Zhuang, Health risk assessment of heavy metals via dietary intake of wheat grown in Tianjin sewage irrigation area, Ecotoxicology, 24(10) (2015) 2115-24. https://doi.org/10.1007/s10646-015-1547-0.

[24] Z. A. Hussein, M. S. Jaafar, A. H. Ismail, Measurement of radium content and radon exhalation rates in Building material samples using passive and active detecting techniques, International Journal of Scientific and Engineering Research, 4 (2013) 1827-1831.

[25] Joint FAO/WHO Expert Committee on Food Additives (JECFA); Combined compendium of food additive specifications: analytical methods, test procedures and laboratory solutions used by and referenced in the food additive specifications. Volume 4 (2000).

[26] International Commission on Radiological Protection (ICRP), Radionuclide release into the environment. Pergamon Press, Oxford, UK (1987). 